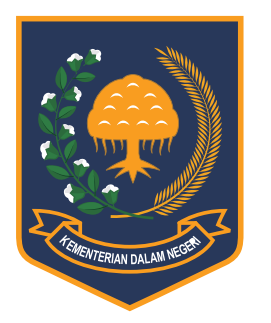

JURNAL BINA PRAJA

e-ISSN: 2503-3360 | p-ISSN: 2085-4323

Accreditation Number

21/E/KPT/2018

http://jurnal.kemendagri.go.id/index.php/jbp/index

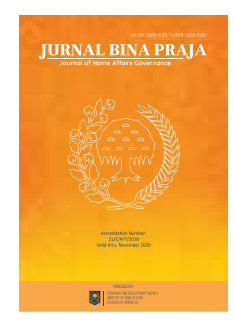

\title{
JUSTICE FOR COMMUNITY: \\ Political Perspective of Michael Sandel's Communitarianism
}

\author{
Nurul Annisa Hamudy," \\ ${ }^{1}$ Sekolah Tinggi Filsafat (STF) Driyarkara \\ Jln. Cempaka Putih Indah 100A \\ Jembatan Serong, Rawasari Jakarta 10520
}

Received: 7 April 2020; Accepted: 1 May 2020; Published online: 28 May 2020

DOI: $10.21787 / \mathrm{jbp} .12 .2020 .43-52$

\begin{abstract}
The ideals of justice are failing, with the widespread violence and discriminatory acts against various communities in Indonesia, despite what Michael Sandel's view that the community's view of good and fair was formed based on the community's beliefs about what is considered as good and fair. Community has an important role in communal living, since each community has a range of values and concepts of good. As such, the concept of a good society cannot simply be derived from the general principle but need to be obtained through the exploration of the community's values and beliefs. For this reason, this study aimed to review the communitarianism-style of justice in the philosophical perspective of Michael Sandel. Using descriptive and documents analysis methods, as well as qualitative approaches, the results of the study showed that justice can be created from the promotion of value. Through a consensus, it is hoped that the government can explore the community's value to be a mutual guideline in community living. This value can be accepted as a common good. Justice in society can only be sensibly created if it starts with the agreed and shared insights. Therefore, justice, according to Sandel, can only be created by using shared community values.
\end{abstract}

Keywords: Justice, Liberalism, Communitarianism, Values, Community, Common Good

\section{INTRODUCTION}

This study was about justice as the ideal that all parties would like to realize, even though in reality, certain communities in Indonesia were suffering from discriminatory treatments and marginalization. This study reviewed the concept of justice with Michael Sandel's approach to communitarianism. As for the term of "justice for the community" referred to in this study, the researcher defined it as the view of good and fair that was formed based on the beliefs about good and fair in certain communities. That is, the concept of a good society cannot simply be derived from the general principle but need to be obtained through the exploration of the community's values and beliefs. Therefore, justice, according to Sandel, can only be created by using shared community values.

Communitarianism put forward the importance of communities and traditions that are ignored by liberalism More specifically, the communitarianism promoted by Michael Sandel is a response to John
Rawls's concept of justice in the book A Theory of Justice (2009). Sandel's critique of Rawls first concerns epistemological (not ontological) criticism, namely the way Rawls constructs theories of justice through transcendental procedures (Sandel, 1998, pp. 7-11). According to Sandel, the implication of this mode is to empty the 'individual' from the ethical context of the community. So, the emphasis is not the individual, but the transcendental epistemology that makes the individual have an ontological status deprived of the empiric of community. Though the individual does not set his own goals but find them in the community where he is. Thus, the view of good and fair, has actually been formed based on beliefs about good and fair in certain communities.

Similar to other critics of liberalism, communitarianism also considers that individualism as a cause of moral decadence and the reduction of community life (Hardiman, 2018, p. 180). By adhering to the value of justice based on the principles of

\footnotetext{
* Corresponding Author

Phone : +6281281224344

Email : nurulannisahamudy@gmail.com
} 
equality and freedom possessed by each individual, Rawls asserted that an individual has the right not to be victimized in the name of the public interest. Therefore, Rawls firmly rejects all actions that can sacrifice individual freedom (Rawls, 2009). Rawls, who was influenced by Immanuel Kant, was considered by the Communitarianism to use a modified principles of liberal society, by ignoring the diversity of communities and cultural particularities. (Farrelly, 2004, p. 98). This is caused by the Rawls mode, which is characterized by transcendental, individual traits are also conceptualized transcendently. The main thing is not the individual, but the transcendental method cannot empty the individual from the empirical of his/her community.

Sandel (1984b) said that Rawlsian's moral subject is an unencumbered self, that is, individuals who are "naked" from their social context, because the transcendental method used by Rawls is emptied from experience (empereia). Moreover, the liberalism concept about individuals who are free from social contexts and formative goals shows as if humans have two separate dimensions in the same self.

"Now the unencumbered self describes first of all the way we stand toward the things we have, or want, or seek. It means there is always a distinction between the values I have and the person I am. To identify any characteristics as my aims, ambitions, desires, and so on, is always to imply some subject " $m e$ " standing behind them, at a certain distance, and the shape of this "me" must be given prior to any of the aims or attributes I bear. One consequences of this distance are to put the self itself beyond the reach of its experience, to secure its identity once and for all. Or to put the point another way, it rules out the possibility of what we might call constitutive ends" (Sandel, 1984b, p. 86).

In short, human cannot deny that they are formed by their environment, and therefore the orientation of the individual is always within their sphere of values and interaction. For this reason, he asserted in the text above, that it is impossible for a subject without a context. The individual has been embedded in his collective community from his birth, as a situated existence.

According to Sandel, liberalism does not take into account the existence of a community as a force to form the identity of each individual. Liberalism considers individuals capable of being independent and independent of the existence of the community. On that basis, liberalism gives the rights relating to guarantees of individual freedom to autonomously determine their life goals, as well as protecting the individuals from the tendency to sacrifice individuals for the common good. The commitment to individual autonomy in determining his choice (selfdetermination), implies that individuals have the right to choose whether they would like to leave or remain as a member of a community. Thus, in Liberalism, collective decisions begin with the supremacy of individuals as moral persons and legal subjects.

The Liberals' Pleonastic glorification of individual autonomy is seen as alienating humans from their communities and forming atomistic individuals who are free from certain views. Therefore, Communitarians call for the need for community ethics and reject individual autonomy because the involvement in a community is not a decision but was an introduction, starting from birth, and it inherits the value of a particular community (Kono, 2016, pp. 34-35). In essence, Sandel's critique is that there can be no subject without a social context, and neither does morality.

Sandel asserted that the subject is always situated, embedded in a certain society with certain values, beliefs, and expectations. As such, the subject does not individually determine his life goals. He did it together with other community members (Sandel, 1998, p. 62). Membership in a community and its attachment to what is the community's horizon are pre-reflexive and embedded in the individual. Sandel's view can be seen in the everyday context of Indonesian society. As a small example, I was born and raised in a Makassar family and adhering to certain values, beliefs, and hopes that have been given from birth. Of course, the values, beliefs, and hopes are different from other people who are born and embrace the values of the Balinese people. The individuals will carry those values, beliefs, and hopes with them throughout their life.

The Indonesian government has attempted to provide justice by providing legal protection for the existing community. This can be seen from the various regulations and policies issued. Legal protection for the rights of minority groups in Indonesia is regulated in Article $28 \mathrm{D}$ and Article $28 \mathrm{I}$ of the 1945 Constitution, and also listed in Article 3 Paragraph (3) of Law No. 39 of 1999 concerning Human Rights. Whereas Article 27 of the International Covenant and Political Rights, which has been ratified by Law Number 12 of 2005, stipulates that various minority groups must have their various rights recognized. In reality, however, the implementation of minority rights in Indonesia is not yet felt. Law enforcement is weak, and equitable development is lacking, and there are other discriminatory treatments toward them (Risdiarto, 2017, p. 125). Coupled with political adversarial characteristics that are not just subject to the law. But still the law is always needed, even if the law does not solve the problem. 
Such as the rejection of the Lesbian, Gay, Bisexual, Transgender, and Queer (LGBTQ) communities in Indonesia, which is increasingly widespread and marked by the various demonstrations denouncing this group. The Saiful Mujani Research Center (SMRC) survey institute research from 2016 to 2017 found that 58.3 percent of Indonesians had heard of LGBT. Of the respondents who knew about LGBT, 41.1 percent said that LGBT people did not have the right to live in Indonesia (Garnesia, 2019). The rejection of this community prompts the Depok city government to carry out raids on the LGBT community (Madrim, 2020).

In the East Kalimantan region, Hadi Mulyadi, the deputy governor, encouraged district and city governments in his province to make regulations that curb LGBT. According to him, LGBT is a disease that can shackle the community. Meanwhile, the Cianjur regency instructed mosque officials, schools and regional officials to socialize the "danger of LGBT and HIV/AIDS." Meanwhile, last October 2018 the Bangka Belitung Province Education Office also asked schools at various levels to harmonize religious education, sports, and biology to prevent the development of LBGT among students (BBC Indonesia, 2018). Violations of justice by administering the values of the local community still occur in parts of Indonesia. Sadly, most people suddenly become moral police and do not consider that discrimination against LGBT as violence as they deserve to be disciplined.

Even the Revision of the Criminal Code (RKUHP) is considered to be increasingly discriminating against Lesbian, Gay, Bisexual, and Transgender (LGBT) groups. This is because Article 421 (1) about molestation (pencabulan) explicitly mentions the same-sex acts. Though the determination of the criminal element of molestation do not require specific gender/sex (CNN Indonesia, 2019). Furthermore, the DPRD of Pariaman City in 2018 has also passed Regional Regulations (Perda), in which articles 24 and 25 concerning Peace and Public Order contain sanctions for Lesbian, Gay, Bisexual, and Transgender. Prior to Kota Pariaman, discrimination towards LGBT was also carried out by the Head of Cianjur District, who issued a Letter to all Sub-District Heads requesting that all of the mosques deliver sermons related to LGBT material. Several other regions also prefer to make similar regulations, such as Depok City, East Kotawaringin District, and West Sumatra Province (Primastika, 2018).

Also, a study by the Setara Institute in Jakarta found that there were 216 cases of attacks on religious minority groups in 2010, 244 cases in 2011, and 264 cases in 2012. Wahid Institute, another observer in Jakarta, documented 92 violations of religious freedom and 184 incidents of religious intolerance in 2011, up from 64 violations and 134 incidents of intolerance in 2010. Persecution and violence directed against minority religious groups are supported by the legal system in Indonesia, in the name of "religious harmony," which in practice undermines the religious freedom.

The 1945 Constitution firmly guarantees religious freedom, as is the International Covenant on Civil and Political Rights which was ratified by Indonesia. However, the Indonesian government has also made (and in recent years strengthened) regulations that resulted in official discrimination of minority religious groups and their followers vulnerable to be attacked by the majority community who are not averse to vigilante actions (Human Rights Watch, 2013).

An example of a case of injustice against the indigenous communities is the case of Kampung Dongi. Kampung Dongi is located in the middle of Soroako City, South Sulawesi.

The ancestors of the Dongi community have occupied their customary territory (wilayah adat) for hundreds of years. But in 1967, the government granted the permit to PT International Nickel Indonesia (PT. INCO) Tbk, to mine nickel ore in the Dongi customary territory. The granting of this permit was made by the government without prior consultation with the indigenous Dongi community as heirs of the customary territory. This area has been inhabited by the Dongi community for hundreds of years and has been passed down from their ancestors (Tim Infokom PB AMAN, 2012).

The case of the Karunsie Dongi community is not the only one in Indonesia. There have also been many indigenous communities who suffered from injustice by losing their rights to their land. The many efforts to exploit natural resources and the transfer of land functions that only benefit certain parties caused the existence of indigenous peoples increasingly at threat. Many of them have been driven from their own land due to land expansion by largescale private companies (Amnesty International, 2020). Even though since 1994, the United Nations (UN) has declared the Rights of Indigenous Peoples (The United Nations Declaration on the Rights of Indigenous Peoples), which contains the basic rights and freedoms of indigenous peoples.

Cited from the website of LBH Jakarta (2016), Indonesia is not doing much effort in applying "Zero Discrimination." The events that occur precisely show the attitude of the country that wants to be neutral, but instead seems ignorant towards discrimination against certain communities. The various incidents that occur show the negligence of the State towards discrimination against certain communities. Some of them; discrimination against the Shi'a community,

\section{Justice for Community:}


which being ostracized, abused, and their rights openly restricted by a group of intolerant people because of their religion and belief, the state stay silent and does not take any action; discrimination against groups of aliran kepercayaan believers in West Java that still unable to obtain their identity cards, resulting in hampered access to the fulfillment of other citizens' rights such as the right to education, the right to health, and others. And many other acts of discrimination committed both by the state and by certain groups of society.

The facts above reveal the reality of justice is never really in favor of those who are marginalized or vulnerable. Therefore, communitarians like Sandel assert that the search for justice can only occur in the order of the community through the promotion of values. Through a consensus, it is hoped that the government can explore the community's value to be a mutual guideline in community living. This value can be accepted as a common good. The common good in a liberal society is regulated in accordance with the patterns of various preferences and conceptions of the good held by individuals. Meanwhile, in a communitarian society, the common good is accepted as a fundamental conception of a good life that determines the 'outlook on life' of the community. Justice in society can only be sensibly created if it starts with the agreed and shared insights, based on that community's view on what they see as good and bad. Not using universal justice which demands the neutrality of the state as an excuse not to apply certain values. So that in the end, they sow the seeds of injustice by ignoring violence and discrimination. Not with universal justice which demands the neutrality of the state as an excuse not to give priority to one value over another (certain values), because ultimately this attitude turns out to still spawn the seeds of injustice by ignoring the violence and discrimination experienced by the community certain (especially minority groups in Indonesia as in the example above).

So far there have been very few studies that have been carried out on that issue. Several studies have discussed the problems faced by a community using the perspective of communitarian political philosophy, but there is no specific review of justice for the community using the communitarian political perspective carried by Michael Sandel. For example, a study conducted by Muthmainnah (2014) with a focus on the discussion of the existence of the Transgender community seen from a communitarian perspective. The results of this study indicate that the problem of the Transgender community in Indonesia is closely related to the value orientation that is built-in society because the country places heterosexuality as a form of normativity. This condition is embedded in society, just as the assumption of communitarianism that the orientation of individual values is sourced from the community.

Another study, by Aida (2005) outlines the communitarian view as a critique of the view of liberalism. The debate between these two streams is the existence of individuals and communities because these two streams have different points of view in placing individuals and communities. Liberalism focuses its attention on individual autonomy, while communitarianism focuses on the community, which is the context of individual existence.

Another study, by Watu (2019), specifically reviews the thoughts of communitarianism from Sandel's perspective. Sandel's alternative view shows the social aspect of human life, that human would fill his life from his past experiences. Likewise, the community's values are the agreed values of the community.

Based on some of the results of the study above, it seems that Michael Sandel's justice for the community has not been much discussed. Therefore, this study seeks to fill the void related to justice for the community from Sandel's communitarian political point of view in understanding community values that are the focus and subject of his attention. Because the case of justice, according to him, can only be answered sensibly if it starts with a horizon of insight that is agreed upon and shared together. Thus, the communitarians put forward their proposals to create justice through the promotion of values. Through a consensus, the government proposes a value that is extracted from the community to be a direction in living together. This study will focus on discussing the values of the community as a place for individual attachment and embeddedness, that need to be considered so that it will produce justice for the community for the common good.

\section{Method}

This study combines descriptive methods and document analysis. The descriptive method is intended to describe community justice as an analysis unit based on facts as they are presented (Kusumo \& Hurriyah, 2019, pp. 95-97). While the document analysis method (Zed, 2004) is intended to gather relevant information on justice from the point of view of Michael Sandel's communitarianism. The information was obtained from literature, extracting materials from books, journals, newspapers, magazines, or study reports related to the study theme adopted by the author and other sources (Hasan, 2002, p. 11). The approach used in this study is a qualitative approach. This approach is suitable since Political Islam is multidimensional (Alwasilah, 
2003). The collection of facts and data was conducted by tracing the news in mainstream mass media to enrich the analysis. The study was conducted for two months from the beginning of 2020 to the end of March 2020. The location of this study was Indonesia. The reason for choosing the location was because Indonesia has variety of communities and there are many cases of injustice against the local community.

\section{RESULTS AND DISCUSSION}

Michael Sandel started his debate with liberalism through his work entitled Liberalism and the Limits of Justice (Sandel, 1998). The work is a critique of John Rawls's view, which argued that society is good if the conditions of society are fair, thus it is necessary to regulate the social order by having two principles of justice, which are the Fairness Principle and The Difference Principle. Rawls orders the principles of justice lexically, thus the first principle must be satisfied before the second principle.

First, Each person has the same indefeasible claim to a fully adequate scheme of equal basic liberties, which scheme is compatible with the same scheme of liberties for all; Second, Social and economic inequalities are to satisfy two conditions: they are to be attached to offices and positions open to all under conditions of fair equality of opportunity (to all citizens); and they are to be to the greatest benefit of the least-advantaged members of society (the difference principle) (Rawls, 2001, pp. 42-43). In short, the first principle relates to the rights of basic individual freedoms, while the second principle relates to the demand for economic equality.

In this sense, Rawls approves a neutral society, which does not prioritize certain values and expectations in society. Anyone, with any view, is guaranteed to be able to participate fully in community life. So that the most important thing in community life is not certain values that are held in high esteem, but justice. In this sense Rawls agrees with the principle or basic value of justice through "original position". This original position is seen as a condition in which people are not affected by personal or particular factors. Anyone, with any view, is guaranteed to participate fully in people's lives, that is what is possible by agreeing on the two principles of justice above. So that the most important thing in life together is not certain values that are held in high esteem, but justice. The principle of justice is that everyone has the same rights to the prevailing moral system. In other words, Rawls wants to defend his claim that the default position reflects a value of freedom and equality (equality), and difference is the value of order (both of them being values of institutional virtue). Thus, these basic values become the criterion for assessing any irregularities. This also has practical implications on the main tasks of the state, not to work on certain virtues, but to guarantee the rights of all parties (Magnis-Suseno, 2005, pp. 200-201).

Sandel's criticism is aimed right at the center of Rawls' view. According to Sandel, all Rawls's constructions are based on certain philosophical anthropologies as such Rawls's thinking position is not neutral. For him, the rational subject which Rawls postulate is unencumbered, not bound by the social environment, individuals without a social context (Sandel, 1998). The atomistic self is free from certain views of good and evil, so it is necessary to construct the principles of justice as if from the ground zero (Rawls's original position concept). Yet, according to Sandel, in reality, there is no such naked self (Sandel, 1998).

\section{A. Community as a Place of Individual Attachment and Embeddedness}

Communitarians put forward the importance of communities and traditions that are ignored by liberalism (Mudzakkir, 2017, p. 149) which relies on self-conceptions that are too individualistic (Bell, 2015, p. 1) (because they refer to Kantian suppositions on individuals as selfish-rational subjects), whereas communitarians consider Rawls's concept of the original position an illogical ahistorical construction. For him, Rawls's transcendental epistemology is at the root of the problem. Sandel (1984b) said that Rawlsian's moral subject is an unencumbered self, that is, individuals who are "naked" from their social context (Sandel, 1984b). It is impossible for a subject without context and morality without a social context. From birth an individual is embedded in his collective community as a situated existence.

Sandel asserted that the subject is always situated, embedded in a certain society with certain values, beliefs, and expectations. As such, the subject does not individually determine his life goals. He did it together with other community members (Sandel, 1998). Membership in a community and its attachment to what is the community's horizon are pre-reflexive and embedded in the individual. The reluctance of the individual to be part of his community and the tendency to reject it, placed him on the outside his community and therefore difficult to form his identity. Because there are certain constitutive things in humans that enable humans to experience a wider mix of horizons. The combination of horizons presupposes the is an existing horizon in humans, and there is no expansion of the horizon without seed of the horizon of value which is constitutively embedded in the individual. Thus, the 
Table 1.

Justice in the Context of Liberalism and Communitarianism

\begin{tabular}{|c|c|c|}
\hline & Rawls & Sandel \\
\hline Approach & Liberalism & Communitarianism \\
\hline Focus & Self & Community \\
\hline Assumption & $\begin{array}{l}\text { The foundation of the Liberalism view is that individuals } \\
\text { are able to autonomously determine their principles } \\
\text { and goals in life, without relying on their inherited } \\
\text { traditions. }\end{array}$ & $\begin{array}{l}\text { - Individuals are not one atomistic and transcendent self } \\
\text { but live together with others. } \\
\text { - There is no individual autonomy in the community. All } \\
\text { policies are determined based on the common good } \\
\text { and the agreement adopted in the community. } \\
\text { - Values that are emphasized are those making the } \\
\text { community the focus and subject of the member's } \\
\text { attention. }\end{array}$ \\
\hline Inspired by & $\begin{array}{l}\text { Jean-Jacques Rousseau, Thomas Hobbes, John Locke, } \\
\text { Immanuel Kant }\end{array}$ & Aristoteles, Hegel, and Charles Taylor \\
\hline
\end{tabular}

individual and the formation of their identity, the values they hold, and their understanding of the world are formed and constructed by society. The individual is also able to express themselves in society as well. The individual has absorbed and internalized the values and views held by the society or community where he grew up (Rusmadji, 2005, p. 36).

The community referred to by Sandel was further divided into three types: instrumental, sentimental, and constitutive. What distinguishes the constitutive community from the others is the fact that the others are related solely to utilitarian or emotional considerations.

"(This) community describes not just what they have as fellow citizens but also what they are, not a relationship they choose (as in a voluntary association) but an attachment they discover, not merely an attribute but a constituent of their identity. In contrast to the instrumental and sentimental conceptions of community, we might describe this strong view as the constitutive conception" (Sandel, 1998).

Sandel's intention, in this case, is to prove that humans can grow by assuming that certain contents are given by their sphere of life. Humans have always had certain qualities in them. To find oneself, people need to have complete environmental support, they must orient themselves to shared values. This implies that the individual is not free in the sense that he absolutely determines the whole direction of his life without participating in a common goal. As such, the basis of society structuring is the view of good and bad in the community itself (Magnis-Suseno, 2005).
Communitarianism emphasizes that norms are always anchored in the community, language, culture and religion. In every community there is a shared and shared moral outlook, this is a normative basis in assessing every action in the community. This communitarian perspective shows that humans cannot be thought of as atomistic or unencumbered self as designed in liberal anthropology. Humans, in the view of liberals, are understood as individuals who are isolated and hover in empty space and placed in spaces of freedom of rights. Yet in reality humans always live in communities, traditions, and social ties (Madung, 2015, p. 236).

Although Sandel proposes that our identity is given by certain communities, it does not mean he is a cultural relativist, because he was aware that constitutive goals might be good or bad, as such, he uses good, bad, and cohesiveness in some of his writings. If he is a cultural relativist, Sandel will not state that constitutive goals can be good or bad because every community adheres to unique values that cannot be compared (Youngmevittaya, 2019, p. 92).

A philosophical search in this direction will be marked by looking for the "good" in the history, especially through exploration of an individual's identity and interpreting his life history (Shaw, 2010, pp. 928-929). Humans are not beings who choose their goals, but one who finds them (Sandel, 1998).

These different starting points have different implications, especially on assumptions, goals, and focus on understanding the nature of individual and community relations. Sandel's communitarianism does not directly criticize individual autonomy in liberalism, but rather its neglect of the social 
conditions needed to exercise that autonomy. According to him, individual autonomy can only be trained and developed in one particular type of environment. To have autonomy or free to act, individuals must have several life choices, and these life choices are provided by their community.

Therefore, the government must intervene to provide or support communities that provide adequate life choices so that individual autonomy can be exercised. This is why communitarianism oppose the neutrality of the state because, in certain cases, the state cannot be neutral. In Sandel's view, the government could not solve a problem without taking into account (on the pretext of neutrality) the arguments in the existing controversy and religion.

The neutrality of the state has considerable consequences. Sandel pointed to the fact that the state stays silent when one group committed blasphemy against another group (Farrelly, 2004).

\section{B. Justice for the Community based on the Common Good}

Sandel's strong argument about justice becomes important because it has to do with how we determine what values are of the most important to a good society (Li, 2018, p. 3). Liberalism assumption that the principles of justice on a society that cannot be based on one particular view of good is impossible (Sandel, 1984b). On the contrary, the individual's view of what is fair and good is always based on perceived loyalty and belief, because individual identity is manifested by his involvement in a particular community (Sandel, 1998). Accordingly, the search for justice can only occur in the community stage, not in the stage of individual autonomy which supports the neutrality of the state (the state must be free from the intervention of the concept of the life of a particular community and not allowed to interfere in determining the concept of the good life of the existing communities).

In this sense, the state must not take a side in determining the concept of a good life, because only by having this neutrality, the right of the individuals as free and independent selves, who are able to have their own values and goals, is respected. This principle will be violated when, for example, the state requires (or even encourages) its citizens to embrace or choose something (for example political choices or certain religious faith choices).

Sandel launched his criticism of the Liberalism view of the neutrality of the state, as in certain cases, the state could not be neutral. He then gave examples of abortion and homosexuality cases (Sandel, 2005, pp. 122-144). For him, whatever decision the government takes in connection with these cases, the state is certainly not neutral because it will still be affected by existing moral and religious considerations. Suppose the government guarantees the right of women to have an abortion. This guarantee means that the government has made a decision based on a certain concept of life (that life does not start during pregnancy, but only after birth).

In the Indonesian context, one of the controversial RKUHP articles is the "criminalization" of victims of rape who are "forced" to have abortions. Article 469 of the RKUHP also states that the prohibition on abortion is aimed at "protecting the womb of the women." The formulation of this article is influenced by the pro-life doctrine that all humans having the right to live, even if the fetus is still in the womb. This doctrine also based on the religious norms which cannot be excluded from people's lives (Syaputra, 2019). Rejection of the homosexual community repeatedly launched by politicians of Islamic parties, who stated that they rejected the existence of LGBT people by issuing new laws that seemed to criminalize sexual relations outside of marriage and homosexual relations in Indonesia (Westcott, 2018).

For Sandel, this attitude is wrong. The government does not show neutrality. Instead, they emphasize the concepts of certain people towards life that only begins when a child is born and toward the sexual life of an individual. With these conditions, it is difficult to have state neutrality. Under scrutiny, what seems like the neutrality of the state is another name for the state's alignments to values that exclude the role of the community from the public sphere. As such, it is not neutral. For him, the country's commitment to a neutral framework among several goals can be seen as a form of value in itself. Furthermore, the value contains a refusal to emphasize a way of life that is based on certain concept of good life (Sandel, 1984a, p. 4). In Sandel's view, the government could not solve a problem without taking into account (on the pretext of neutrality) the arguments in the existing controversy and religion.

Sandel also said that the neutrality of the state had considerable consequences, by pointing to the fact that the state stays silent toward the blasphemy of one group against another group (Farrelly, 2004). The state, based on constitutional provisions, does not interfere with blasphemy matters between groups on the principle of neutrality of the state. On that basis, the communitarians reject the neutrality of the state when dealing with a plurality of values. The state should promote collective rights as a force of solidarity and a motivator for political integration. For communitarianism, the state and society are not two separate entities. It is argued that the political integration of a country would only be achieved within the community ethos in the form of cultural 
values (Kono, 2016) and that communities continue to have a role in the shared life because each has a trove of values and concepts of the good life. The scope of cultural rights and indigenous communities is not yet seen in the "principle of difference" that is carried by Rawls, even though the need is so clear. Because in many debates, the principle of Rawls difference is understood more as a matter of socio-economic inequality, even though it is also necessary to extend it to cultural rights!

As such, taking into account the existence of a community is a tolerant political attitude. Thus, the state needs to go beyond neutrality if a case of intolerance occurs. Anomalies of state neutrality like this often occur in Indonesia, where the state stays silent (neutral) in intolerance cases that harass certain communities. The state does nothing even when there are casualties. For example, the state does nothing during an attack on the Ahmadiyya community, which proves the naïve neutrality of the state. The consideration of the judges for the sixmonth incarceration sentence to one of the members, who was also a victim of the rampage of the intolerant group, showed that the Serang District Court did not solve the violence case against the Ahmadiyah community as a representation of the state (Pratama et al., 2016, p. 4). The Ahmadiyya community is often the target of intolerance and persecution. Komnas HAM's annual report showed that, from January to December 2016, there were 22 out of 97 complaints of violations of the right to freedom of religion and belief against the Ahmadiyya community (Hamimah, 2018, p. 24).

It is not only the Ahmadiyah community who is marginalized, but the various indigenous communities have also been treated badly in Indonesia. One of them is the Karuhun Sunda Wiwitan indigenous community in Cigugur, West Java, which also endure systemic discrimination. The problem stems from the policy of keeping the religion column on the ID card (KTP) blank for the community of penghayat kepercayaan believers. Constitutional Court Judge Decision No. 97 / PUU-XIV / 2016 granted a request for judicial review of Article 61 Paragraphs (1) and (2), and Article 64 Paragraph (1) and (2) of Law Number 24 of 2013 concerning Amendments to Law Number 23 of 2006 concerning Population Administration, related to the regulation of keeping the religious column on family cards (KK) and identity cards blank (Andhika, 2019, p. 283). Even though the population administration for the penghayat kepercayaan believers are still served by the related agency, and they are recorded in the population database, in reality, that provision creates discrimination. The penghayat kepercayaan community finds it difficult to get married, arrange for birth certificates, access jobs, and access social security (Erdianto \& Nadlir, 2017). The Baduy community also endured the injustice committed by the state because they cannot have a marriage certificate. Based on PP No.37 of 2007, to arrange a marriage certificate recognized by the state, they must have a marriage letter from the local religious authority registered at the Ministry of Education and Culture. Without a marriage certificate, the birth certificate of their child only listed the mother's name as the single parent (Sukirno, 2018, p. 234).

Maintaining the integrity of the nation with so much diversity and tangled history is not an easy matter, but it is not impossible. When the government is willing to unravel this tangled history, namely by making the community the focus of its attention, this problem would be solved. Community as a place of individual adhesion and embeddedness must be put into the focus of the government's attention. If the growth and development of the community is in the government's focus, automatically the individuals who are members will also be in its focus.

This is the reason the Communitarianism concept of justice is important for Indonesia, since, in reality, the concept of a good society cannot simply be derived from the general principle but need to be obtained through the exploration of the community's values and beliefs. Therefore, the concept of a just society can only be created by using the shared values from that community itself. The fact that there are shared values that precede the individual does not deny the individual's rights to consider the values inherent in him but makes it sharper.

\section{Conclusion}

Sandel's communitarianism does not directly criticize individual autonomy in liberalism, but rather its neglect of the social conditions needed to exercise that autonomy. The communitarianism view is that humans cannot be thought of as atomistic individuals or "unencumbered self," as expressed by liberal thinkers. Humans, in the liberal view, are seen as isolated individuals, hovering in empty space, and placed in spaces of freedom of rights, which then support the concept of neutrality of the state (not allowed to interfere in determining the concept of good life for the existing communities). In contrast, the Communitarianism, view individuals as not an atomistic and transcendent self, because in reality, humans always live together with others in communities, traditions, and social ties. This is where Sandel's view is important, he wants to show the social side of a human's life. Humans never carve their lives from the void of self, as what the liberalism put forward, but instead, they rely on their existing experience. 
Sandel asserted that the subject is always situated, embedded in a certain society with certain values, beliefs, and expectations. As such, the subject does not individually determine his life goals. He did it together with other community members. Membership in a community and its attachment to what is the community's horizon are pre-reflexive and embedded in the individual.

On this basis, this study aims to rediscover justice for the community through the analysis of communitarian political philosophy, which proposes to create justice through the promotion of values within the community. Through a consensus, it is hoped that the government can explore the community's value to be a mutual guideline in community living. This value can be accepted as a common good. Justice in society can only be sensibly created if it starts with the agreed and shared insights. Community, which has been discriminated against and marginalized, has an important role in the communal living, since each community has its own range of values and concepts of good life. The purpose of this study is to look for and take into account the existence of the community as a tolerant political attitude because the state needs to go beyond neutrality in the event of intolerance, as is the case in Indonesia. In a country steep in diversity, both ethnic, cultural, linguistic, and religious, it is very difficult to implement a liberal understanding that upholds individual freedom. Communitarianism seems to be a fairly appropriate view to find justice for the existing community of Indonesia.

The concept of a good society cannot simply be derived from the general principle but need to be obtained through the exploration of the community's values and beliefs. Therefore, the concept of a just society can only be created by using the shared values from that community itself.

\section{ACKNOWLEDGMENT}

The Author would like to thank Mr. Lutfi Assyaukanie (who first introduced the views of Michael Sandel) and Father B. Herry-Priyono for inspiring teaching and discussion in STF Driyarkara Suggestions and constructive criticism from him would be highly appreciated.

\section{REFERENCES}

Aida, R. (2005). Liberalisme dan Komunitarianisme: Konsep tentang Individu dan Komunitas. Demokrasi, 4(2), 95-106. http: / /ejournal.unp. ac.id/index.php/jd/article/viewFile/1063/896 Alwasilah, A. C. (2003). Pokoknya Kualitatif: DasarDasar Merancang dan Melakukan Penelitian Kualitatif. Pustaka Jaya.
Amnesty International. (2020, February 21). Lindungi Hak-hak Warga Adat Maluku dari Ekploitasi Lahan. Amnesty.Id. https://www.amnesty.id/ lindungi-hak-hak-warga-a dat-maluku-dariekploitasi-lahan/

Andhika, M. B. S. (2019). Perlindungan Hukum terhadap Hak Konstitusional Warga Negara Penganut Kepercayaan. SYARIATI : Jurnal Studi Al-Qur'an Dan Hukum, 5(2), 283-292. https:/ / ojs.unsiq.ac.id/index.php/syariati/article/ view/1198

BBC Indonesia. (2018, November 12). Marak perda anti-LGBT "demi moral publik", bagaimana nalar hukumnya? Bbc.Com. https://www.bbc.com/ indonesia/indonesia-46170154

Bell, D. A. (2015). Communitarianism. In Wiley Encyclopedia of Management (Vol. 2, pp. 1-3). John Wiley \& Sons, Ltd. https://doi. org/10.1002/9781118785317.weom020091

CNN Indonesia. (2019, September 19). RKUHP Dinilai Akan Perparah Diskriminasi terhadap LGBT. Cnnindonesia.Com. https://www.cnnindonesia. com/nasional/20190918210559-12-431758/ rkuhp-dinilai-akan-perparah-diskriminasiterhadap-lgbt

Erdianto, K., \& Nadlir, M. (2017, December 6). Hapus Diskriminasi Penghayat Kepercayaan (S. Gatra (ed.)). Kompas.Com. https://nasional.kompas. $\mathrm{com} / \mathrm{read} / 2017 / 12 / 06 / 06050061 /$ hapusdiskriminasi-penghayat-kepercayaan

Farrelly, C. (2004). Contemporary Political Theory: A Reader. SAGE Publications Ltd. https://doi. org/10.4135/9781446215272

Garnesia, I. (2019, June 29). Pandangan Terhadap LGBT: Masih Soal Penyakit Sosial dan Agama (I. L. A. Bhaskara (ed.)). Tirto.Id. https://tirto.id/ pandangan-terhadap-lgbt-masih-soal-penyakitsosial-dan-agama-edju

Hamimah, S. (2018). Dinamika Kasus Ahmadiyah dan Aliran Kepercayaan Lainnya Serta Penyelesaiannya Melalui Hukum Tertulis di Indonesia. Syariah Jurnal Hukum Dan Pemikiran, 18(1), 19-29. https://doi.org/10.18592/ Sy.v18i1.2062

Hardiman, F. B. (2018). Demokrasi dan Sentimentalitas. Kanisius.

Hasan, I. (2002). Pokok-pokok Materi Metodologi Penelitian dan Aplikasinya. Ghalia Indonesia.

Human Rights Watch. (2013, February 28). Atas Nama Agama: Pelanggaran terhadap Minoritas Agama di Indonesia (E. Pearson \& P. Kine (eds.)). Human Rights Watch. https: //www.hrw.org/ report/2013/02/28/religions-name/abusesagainst-religious-minorities-indonesia

Kono, R. (2016). Senandung Suara-suara Minor. Matahari. 
Kusumo, R., \& Hurriyah, H. (2019). Populisme Islam di Indonesia: Studi Kasus Aksi Bela Islam oleh GNPF-MUI Tahun 2016-2017. Jurnal Politik, 4(1), 87-113. https://doi.org/10.7454/jp.v4i1.172

LBH Jakarta. (2016, March 1). Tahun 2016, Negara Masih Lalai Mencegah Terjadinya Diskriminasi. Bantuanhukum.or.Id. https:/ / www. bantuanhukum.orid/web/tahun-2016-negaramasih-lalai-mencegah-terjadinya-diskriminasi/

Li, C. (2018). Community without Harmony? A Confucian Critique of Michael Sandel. In M. J. Sandel \& P. J. D’Ambrosio (Eds.), Encountering China: Michael Sandel and Chinese Philosophy (pp. 3-18). Harvard University Press. https:// doi.org/10.2307/j.ctvqht3f.4

Madrim, S. (2020, January 15). Pemkot Depok Diminta Cabut Imbauan Razia Komunitas LGBT. VOA Indonesia. https: //www.voaindonesia.com/a/ pemkot-depok-diminta-cabut-imbauan-raziakomunitas-lgbt-/5246249.html

Madung, O. G. (2015). Pancasila dalam Pusaran Diskursus Liberalisme versus Komunitarisme. Khazanah: Jurnal Studi Islam Dan Humaniora, 13(2), 231. https://doi.org/10.18592/ khazanah.v13i2.768

Magnis-Suseno, F. (2005). Pijar-pijar Filsafat: Dari Gatholoco ke Filsafat Perempuan, dari Adam Müller ke Postmodernisme. Kanisius.

Mudzakkir, A. (2017). Kembalinya Tradisi: Rasionalitas dan Etika Komunitarian Alasdair MacIntyre. Societas Dei: Jurnal Agama Dan Masyarakat, 4(2), 147-163. https://doi. org/10.33550/sd.v4i2.70

Muthmainnah, L. (2014). Problem Eksistensi Transgender di Indonesia dari Perspektif Politik Kaum Komunitarian. Jurnal Filsafat, 24(1), 5878. https://doi.org/10.22146/jf.34759

Pratama, I. M. J. U., Wisanjaya, I. G. P. E., \& Arsika, I. M. B. (2016). Penyelesaian Kasus Kekerasan Terhadap Jemaat Ahmadiyah di Wilayah Cikeusik Indonesia dalam Perspektif Kovenan Internasional tentang Hak-hak Sipil dan Politik. Kertha Negara, 4(3), 1-6. https: / /ojs.unud.ac.id/ index.php/Kerthanegara/article/view/20148

Primastika, W. (2018, December 7). Perda yang Mendiskriminasi LGBT Disebut Melanggar Konstitusi (M. S. Handayani (ed.)). Tirto.Id. https://tirto.id/perda-yang-mendiskriminasilgbt-disebut-melanggar-konstitusi-da8d

Rawls, J. (2001). Justice as Fairness: A Restatement (J. Rawls \& E. Kelly (eds.)). Harvard University Press.

Rawls, J. (2009). A Theory of Justice. Harvard University Press. https://doi.org/10.2307/j. ctvkjb25m

Risdiarto, D. (2017). Perlindungan Terhadap
Kelompok Minoritas di Indonesia dalam Mewujudkan Keadilan dan Persamaan di Hadapan Hukum. Jurnal RechtsVinding, 6(1), 125-142. https://rechtsvinding.bphn.go.id/ ejournal/index.php/jrv/article/view/120

Rusmadji, A. (2005). Berkenalan dengan Komunitarianisme. Limen: Jurnal Agama Dan Kebudayaan, 1(2), 30-54. http://jurnal.stftfajartimur.ac.id/index.php/lim/article/view/45

Sandel, M. J. (1984a). Liberalism and Its Critics (M. J. Sandel (ed.)). New York University Press.

Sandel, M. J. (1984b). The Procedural Republic and the Unencumbered Self. Political Theory, 12(1), 81-96. https://doi. org/10.1177/0090591784012001005

Sandel, M. J. (1998). Liberalism and the Limits of Justice. Cambridge University Press. https://doi. org/10.1017/CB09780511810152

Sandel, M. J. (2005). Public Philosophy: Essays on Morality in Politics. Harvard University Press.

Shaw, C. K. Y. (2010). Civic Republicanism and Democratic Politics-Michael Sandel and Contemporary Theories of Political Community. EurAmerica, 40(4), 923-945. https://www. ea.sinica.edu.tw/eu_file/129290367914.pdf

Sukirno. (2018). Diskriminasi Pemenuhan Hak Sipil Bagi Penganut Agama Lokal. Administrative Law \& Governance Journal, 1(3), 231-239. https:// doi.org/10.14710/alj.v1i3.231-239

Syaputra. (2019, October 9). Rumusan Aborsi dalam RKUHP. DetikNews. https://news.detik.com/ kolom/d-4739470/rumusan-aborsi-dalamrkuhp

Tim Infokom PB AMAN. (2012, September 24). Kasus Komunitas Karunsie Dongi. Aman.or.Id. https:// www.aman.or.id/2012/09/kasus-komunitaskarunsie-dongi/

Watu, W. B. (2019). Komunitarianisme Michael Sandel: Pemikiran Dasar, Relevansi Politis, dan Kritik Atasnya (pp. 1-13). https://www.academia. edu/39965957/Komunitarianisme_Michael_ Sandel_Pemikiran_Dasar_Relevansi_Politis_dan_ Kritik_Atasnya

Westcott, B. (2018, February 26). Rencana Hukum Pidana Gay di Indonesia: Ketakutan dalam Komunitas LGBT. Matamatapolitik.Com. https: / / www.matamatapolitik.com/rencana-hukumpidana-gay-di-indonesia-ketakutan-di-antarakomunitas-lgbt-terus-berlanjut/

Youngmevittaya, W. (2019). A Critical Reflection on Michael J. Sandel: Rethinking Communitarianism. Journal of Social Sciences, 15(1), 83-116. https://doi.org/10.14456/ jssnu.2019.4

Zed, M. (2004). Metode Penelitian Kepustakaan. Yayasan Pustaka Obor Indonesia. 